\title{
VEGF modulation and renal effects: Case report and review of the literature
}

\author{
Camilo Pena-Hernandez MD, Rubayat M Rahman MD, Subhanudh Thavaraputta MD, Nishi Garg MD
}

\begin{abstract}
Angiogenesis has been known for decades to be an essential step in cancer growth. In recent years, the vascular endothelial growth factor (VEGF) family was identified as a crucial stimulus (and product by tumors) for neovascularization, nutrition, oxygen delivery, and metastatic dissemination; VEGF inhibition currently has an important role in cancer therapy. The development and increased use of VEGF inhibitors has led to the identification of side effects and renal complications. Vascular endothelial growth factor is produced by renal podocytes to maintain a healthy endothelium, mesangium, and tubular structures. With the disruption of nutritional processes in the kidney, there can be renal injury starting at the cellular level and referred to by some experts as anti-VEGF nephropathy (hypertension, thrombotic microangiopathy, proteinuria, renal failure).

Here we present the case of a man with renal cell carcinoma who was treated with surgical resection and later started on sunitinib. He developed several acute and chronic medical problems, including some related to anti-VEGF toxicity.
\end{abstract}

Keywords: Vascular endothelial growth factor, sunitinib, anti-VEGF nephropathy, renal cell carcinoma, podocytes, thrombotic microangiopathy, hypertension, acute renal injury

\begin{abstract}
Angiogenesis has been known to be an essential step in cancer growth for decades. In recent years, the vascular endothelial growth factor (VEGF) family was identified as a crucial stimulus (and product by tumors) for neovascularization, nutrition, oxygen delivery, and metastatic dissemination; VEGF inhibition currently has an important role in cancer therapy. ${ }^{1}$ The development and increased use of VEGF inhibitors have led to the identification of side effects and renal complications. Vascular endothelial growth factor is produced by renal podocytes to maintain a healthy endothelium, mesangium, and tubular structures. With the disruption of nutritional processes
\end{abstract}

Corresponding author: Camilo Pena

Contact Information: Camilo.pena@ttuhsc.edu DOI: 10.12746/swrccc.v7i27.519 in the kidney, there can be renal injury starting at the cellular level which has been called anti-VEGF nephropathy (hypertension, thrombotic microangiopathy, proteinuria, renal failure). ${ }^{2}$ This case report demonstrates some of these side effects.

\section{CASE}

A 71-year-old man with a history of stage IV renal cell carcinoma status post right radical nephrectomy, chronic kidney disease stage III, hypertension, hyperlipidemia, and hypothyroidism was admitted with dizziness, weakness, and decreased urine output for two days starting after his latest round of chemotherapy. He noted shortness of breath, orthopnea, and nausea. His wife also reported that he had decreased oral intake. His medical history included clear cell carcinoma with extensive sarcomatoid features (pT4, 
$\mathrm{pNx}, \mathrm{pMx}$, stage IV) treated with right radical open nephrectomy. After surgery, he received eight cycles of gemcitabine. In August 2015 sunitinib (Sutent, Pfizer Inc.) was started at $25 \mathrm{mg}$ daily with a schedule of four weeks on and two weeks off. The dose was increased to $50 \mathrm{mg}$ daily for a brief period but then reduced to $37.5 \mathrm{mg}$ daily due to significant transaminitis. He was also restarted on a monthly schedule of gemcitabine (Gemzar, Eli Lilly) every four months before this hospitalization.

Upon admission, the physical examination revealed no significant abnormalities other than orthostatic hypotension, pale skin, and conjunctivae. The initial laboratory showed pancytopenia, hypoglycemia, elevated creatinine $(2.9 \mathrm{mg} / \mathrm{dl}$ from a baseline serum creatinine of $\sim 1.2 \mathrm{mg} / \mathrm{dl})$, hyperkalemia $(6.3 \mathrm{mEq} / \mathrm{L})$, high anion gap metabolic acidosis, hypoalbuminemia, hyperbilirubinemia, and transaminitis (AST 2,600 IU/L, ALT 1,500 IU/L). The peripheral blood film revealed macrocytosis and polychromasia with burr cells, target cells, and tear drop cells with large platelets. A chest $\mathrm{x}$-ray showed mild cardiomegaly with pulmonary edema. Additional workup revealed elevated D-dimer $(44,946 \mathrm{ng} / \mathrm{ml})$, lactate dehydrogenase (961 Units/L), haptoglobin $(250 \mathrm{mg} / \mathrm{dl})$, and a mildly decreased ADAMTS13 activity (30\%) with high inhibitor 0.5 (reference range $<0.4$ ). His fractional excretion of sodium was $2 \%$, and urine eosinophil stain was negative. Urine microscopy revealed muddy brown casts with isomorphic hematuria. He was diagnosed with chemotherapyinduced thrombotic microangiopathy and acute liver injury in addition to combined pre-renal and chemotherapy-induced acute kidney injury for which the chemotherapy was held.

During his hospitalization, he also developed acute congestive heart failure with hypoxemic respiratory failure and was transferred to the medical intensive care unit. Transthoracic echocardiogram revealed new findings of heart failure with an ejection fraction of $25-29 \%$ and no regional wall motion abnormalities. Urine output never improved. After discussion with his providers, the patient and his family opted for inpatient hospice to allow a natural death, and later he was transferred to the supportive care unit. The patient died shortly afterward.

\section{Discussion}

\section{VEGF MODULATION AND RENAL EFFECTS}

The refined permeability of the glomerular capillary wall is mediated mainly by three factors: the negatively charged glomerular basement membrane (GBM), the podocytes or visceral epithelial cells, and the fenestrated endothelial cells. The podocyte produces and secretes vascular endothelial growth factor (VEGF) which is specific for the survival, nutrition, and development of glomerular capillaries, mesangium, and glomerular endothelial cells which are capable of expression of VEGF receptors in the kidney. ${ }^{3}$ There is more than one VEGF ligand produced in the body, and these interact with different cells, such as the endothelial cells. VEGF-A binds to its specific receptor (VEGFR- 1, 2, 3) and has an essential role in promoting angiogenesis and therefore a healthy endothelium (Figure 1).

In 1971, Dr. Juda Folkman proposed the hypothesis that cancer growth was dependent on neovascularization for nutrition. Since then, oncologists have tried to develop therapies that prevent malignancies from getting the nutrients needed for adequate

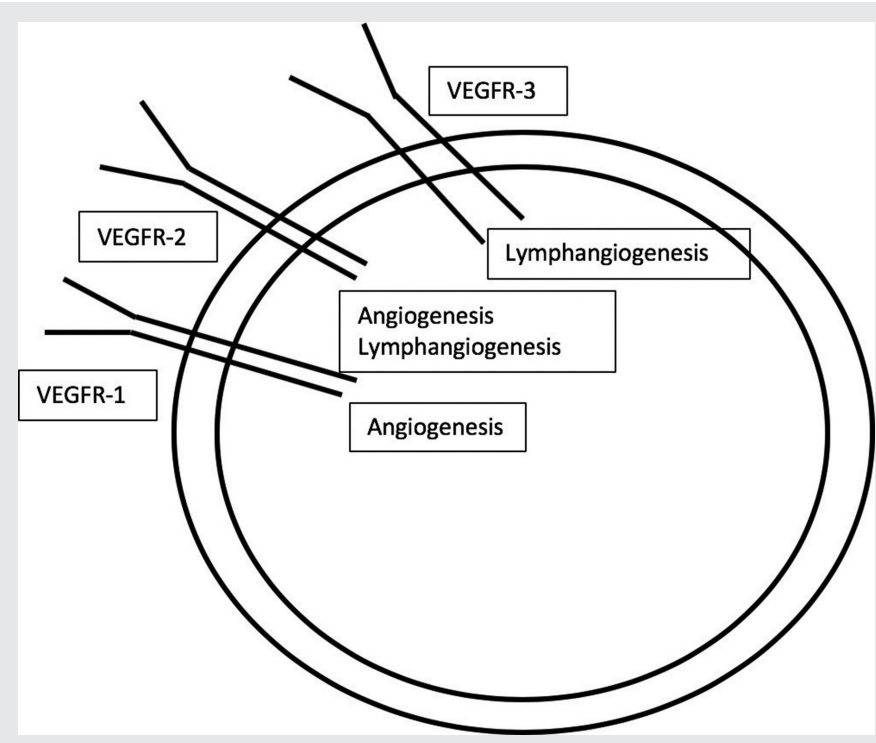

Figure 1. VEGF family, receptors, and effects. 
Table 1. FDA approved anti-VEGF drugs

\begin{tabular}{|l|l|}
\hline Name & Type \\
\hline Bevacizumab & Monoclonal antibody \\
\hline Sorafenib & VEGF signal inhibitor \\
\hline Sunitinib & VEGF signal inhibitor \\
\hline Pazopanib & VEGF signal inhibitor \\
\hline
\end{tabular}

development, and these efforts led to the development of VEGF modulators. ${ }^{4}$ Table 1 details some of the VEGF modulators currently approved by the Federal Drug Administration.

Our patient was taking sunitinib, a VEGF modulator which affects the intracellular pathway of tyrosine kinase inhibition that decreases the VEGF effect distally to the response signaling. Swelling of the glomerular endothelial cells with loss of glycocalyx, reductions of nephrin (a protein necessary for a healthy filtration barrier), disruption of the slit diaphragms, and fibrin deposition cause microangiopathy and thrombosis. ${ }^{4}$

Many cases have been reported in the literature over the last five years describing VEGF modulation and renal involvement (Table 2). In contrast to the usual time course for nephrotoxicity related to medication side effects, VEGF modulators may take up to three years of chronic therapy to produce renal side effects. ${ }^{2}$ This may be related, in part, to the difficulty in linking some of the side effects with the medication early during the treatment course. Side effects, such as new onset hypertension, worsening chronic hypertension, new onset/worsening proteinuria, focal and segmental glomerulosclerosis, and even thrombotic microangiopathy (TMA), may go unrecognized while the patients are taking VEGF modulators. The renal effects we discuss below are the ones most commonly described in the literature.

\section{HYPERTENSION}

One of the most significant side effects encountered at the time VEGF inhibitors are started is hypertension. Changes in blood pressure develop in nearly all patients started on these medications. Hypertensive blood pressure levels are noted in $19-24 \%$ of patients receiving VEGF modulators, but this can increase to $80 \%$ with some of the newly approved and experimental forms of these medications. ${ }^{5,6}$ It can also happen with intra-ocular injections used by some ophthalmologists for diseases like age-related macular degeneration. ${ }^{7}$

As a consequence of VEGF inhibition, there is a decrease in nitric oxide (NO) production resulting in peripheral vasoconstriction and increased vascular resistance. Because VEGF has an active role in endothelial health, blocking VEGF will cause endothelial dysfunction with increased production of endothelin-1 (ET-1), which is a strong vasoconstrictor (Figure 2). ${ }^{8}$ Management of high blood pressure largely depends on the experience of the providers in charge of the patient care and comorbidities; the target per JNC-7 blood pressure goals is $<140 / 90 \mathrm{mmHg}$. The National Cancer Institute also recommends close monitoring of blood pressure weekly during the first round of VEGF inhibitors and then every 2-3 weeks for the duration of treatment. ${ }^{9}$

Calcium channel blockers (especially dihydropyridine) have been widely used and recommended by experts due to the reduction in smooth muscle contractility of the vessels affected by the lack of $\mathrm{NO}$ and increased of ET-1. ${ }^{10}$ Angiotensin-converting enzyme inhibitors and angiotensin II receptor blockers have also been reported as adequate therapies for VEGF related hypertension, especially when proteinuria is a comorbid condition.

\section{THROMBOTIC MICROANGIOPATHY}

With the disruption of the healthy endothelium secondary to VEGF inhibition, there will be fibrin deposition and ultimately enhanced clotting with the development of thrombotic microangiopathy (TMA). The incidence of TMA is high, ${ }^{11}$ and expert opinion considers TMA as the most common complication of VEGF inhibitors. ${ }^{2}$ Our patient was also receiving gemcitabine, a drug known to cause TMA $^{12}$ (not the focus of this review but essential to know). 
Table 2. Case reports between 2013 and 2018

\begin{tabular}{|c|c|c|c|}
\hline Year & Case Report Title & VEGF Modulator & Renal Effects \\
\hline 2018 & $\begin{array}{l}\text { Lenvatinib-induced renal failure: two first-time case } \\
\text { reports and review of literature }{ }^{15}\end{array}$ & Lenvatinib & $\begin{array}{l}\text { Glomerular injury and } \\
\text { proteinuria Tubulointerstitial } \\
\text { injury }\end{array}$ \\
\hline 2017 & $\begin{array}{l}\text { BRAF signaling pathway inhibition, podocyte injury, } \\
\text { and nephrotic syndrome }\end{array}$ & $\begin{array}{l}\text { Dabrafenib and } \\
\text { Trametinib }\end{array}$ & Nephrotic syndrome \\
\hline 2017 & $\begin{array}{l}\text { Posterior reversible encephalopathy syndrome (PRES) } \\
\text { with sub-arachnoid hemorrhage after bevacizumab } \\
\text { and } 5-\mathrm{FU}^{17}\end{array}$ & Bevacizumab & Severe hypertension \\
\hline 2016 & $\begin{array}{l}\text { Fatal posterior reversible leukoencephalopathy } \\
\text { syndrome associated coma induced by bevacizumab in } \\
\text { metastatic colorectal cancer and review of literature }\end{array}$ & Bevacizumab & Severe hypertension \\
\hline 2017 & $\begin{array}{l}\text { Posterior reversible encephalopathy syndrome with } \\
\text { concurrent nephrotic syndrome in a patient treated with } \\
\text { pazopanib for metastatic renal cell carcinoma: case } \\
\text { report and review of the literature }\end{array}$ & Pazopanib & Severe hypertension \\
\hline 2016 & $\begin{array}{l}\text { Anti-VEGF-related thrombotic microangiopathy in a } \\
\text { child presenting with nephrotic syndrome }\end{array}$ & Bevacizumab & Thrombotic microangiopathy \\
\hline 2015 & $\begin{array}{l}\text { Symptomatic secondary polycythemia induced by anti- } \\
\text { VEGF therapy for the treatment of metastatic renal cell } \\
\text { carcinoma: a case series and review. }\end{array}$ & $\begin{array}{l}\text { Axitinib, Pazopanib, } \\
\text { Bevacizumab, } \\
\text { Sorafenib }\end{array}$ & Severe hypertension \\
\hline 2015 & $\begin{array}{l}\text { Intravitreal antivascular endothelial growth factor } \\
\text { therapy may induce proteinuria and antibody mediated } \\
\text { injury in renal allografts }\end{array}$ & $\begin{array}{l}\text { Intravitreal } \\
\text { Bevacizumab }\end{array}$ & Proteinuria \\
\hline 2014 & $\begin{array}{l}\text { A case of glomerulopathy associated with the vascular } \\
\text { endothelial growth factor inhibitor bevacizumab }{ }^{23}\end{array}$ & Bevacizumab & Proteinuria \\
\hline 2014 & $\begin{array}{l}\text { Clinicopathological spectrum of kidney diseases } \\
\text { in cancer patients treated with vascular endothelial } \\
\text { growth factor inhibitors: a report of } 5 \text { cases and review } \\
\text { of literature }\end{array}$ & $\begin{array}{l}\text { Bevacizumab, } \\
\text { Sorafenib }\end{array}$ & $\begin{array}{l}\text { Hypertension, proteinuria, } \\
\text { and thrombotic } \\
\text { microangiopathy }\end{array}$ \\
\hline 2014 & $\begin{array}{l}\text { Renal injury following intravitreal anti-VEGF } \\
\text { administration in diabetic patients with proliferative } \\
\text { diabetic retinopathy and chronic kidney disease-a } \\
\text { possible side effect?? }\end{array}$ & $\begin{array}{l}\text { Intravitreal VGEF } \\
\text { inhibitor (not } \\
\text { specified) }\end{array}$ & $\begin{array}{l}\text { Chronic kidney disease } \\
\text { progression }\end{array}$ \\
\hline 2013 & $\begin{array}{l}\text { Osteonecrosis of the mandible due to anti-angiogenic } \\
\text { agent, bevacizumab }^{26}\end{array}$ & Bevacizumab & Osteonecrosis of the jaw \\
\hline
\end{tabular}




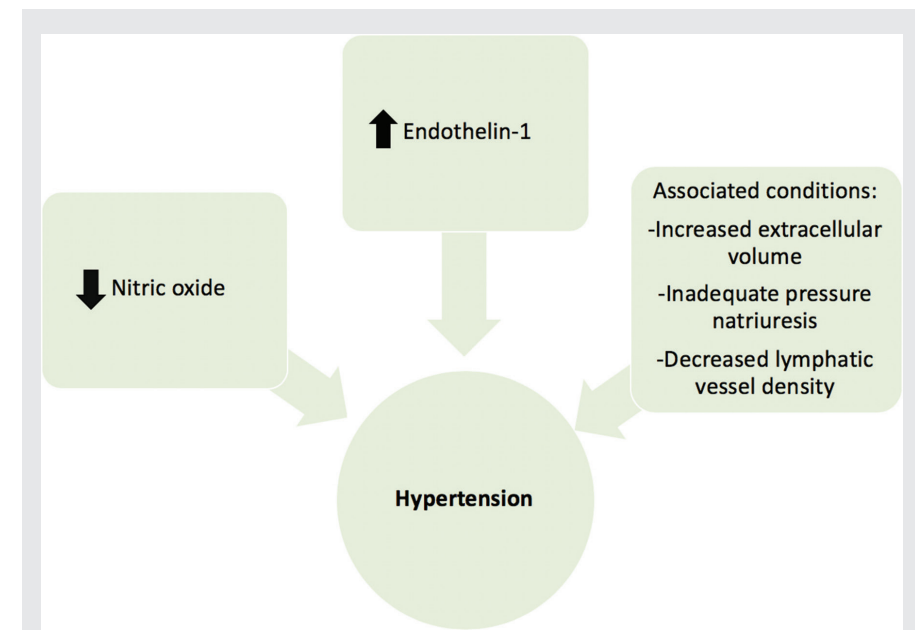

Figure 2. Mechanisms linked to hypertension with VEGF inhibition.

Discontinuation of the VEGF modulator has become standard management. Upon stopping the offender drug, blood pressure control needs to be optimized to avoid more endothelial injury, and other medications that might exacerbate the endothelial injury need to be adjusted and sometimes stopped (e.g., calcineurin inhibitor, clopidogrel, ticlopidine). In general, plasmapheresis is avoided, since it has not shown any benefit in previous studies. ${ }^{13}$ The prognosis seems to be variable and mostly dependent on the timing of diagnosis and comorbidities. With early diagnosis and discontinuation of the drug, one may expect a regression of the microangiopathy and thrombosis. ${ }^{14}$

\section{SUMMARY}

This patient developed acute kidney injury with anemia, thrombocytopenia, and laboratory tests consistent with microangiopathic hemolytic anemia. He was hypertensive throughout his hospitalization. His clinical condition deteriorated despite supportive care and withholding chemotherapeutic agents. Multiple organs rapidly failed. This case illustrates the severe side effects associated with VEGF inhibitors.
Article citation: Pena-Hernandez C, Rahman RM, Thavaraputta S, Garg N. VEGF modulation and renal effects: case report and review of the literature. The Southwest Respiratory and Critical Care Chronicles 2019;7(27):58-63

From: The Department of Internal Medicine at Texas Tech University Health Sciences Center in Lubbock, Texas

Submitted: $11 / 7 / 2018$

Accepted: 12/16/2018

Reviewer: Patricia Aristimuno MD

Conflicts of interest: none

This work is licensed under a Creative Commons Attribution-ShareAlike 4.0 International License.

\section{REFERENCES}

1. Hicklin DJ, Ellis LM. Role of the vascular endothelial growth factor pathway in tumor growth and angiogenesis. J Clin Oncol 2005;23(5):1011-1027.

2. Eremina V, Jefferson JA, Kowalewska J, et al. VEGF inhibition and renal thrombotic microangiopathy. N Engl J Med 2008;358(11):1129-1136.

3. Skorecki K, Chertow GM, Marsden PA, et al. Brenner and Rector's The Kidney. Vol 10th: ELSEVIER; 2016.

4. Gurevich F, Perazella MA. Renal effects of anti-angiogenesis therapy: update for the internist. Am J Med 2009; 122(4):322-328.

5. Zhu X, Wu S, Dahut WL, Parikh CR. Risks of proteinuria and hypertension with bevacizumab, an antibody against vascular endothelial growth factor: systematic review and meta-analysis. Am J Kidney Dis 2007;49(2):186-193.

6. Robinson ES, Matulonis UA, Ivy P, et al. Rapid development of hypertension and proteinuria with cediranib, an oral vascular endothelial growth factor receptor inhibitor. Clin J Am Soc Nephrol 2010;5(3):477-483.

7. Lovell AR, Ernst ME. Drug-induced hypertension: focus on mechanisms and management. Curr Hypertens Rep 2017; 19(5):39.

8. Kappers MH, van Esch JH, Sluiter W, et al. Hypertension induced by the tyrosine kinase inhibitor sunitinib is associated with increased circulating endothelin-1 levels. Hypertension 2010;56(4):675-681.

9. Small HY, Montezano AC, Rios FJ, et al. Hypertension due to antiangiogenic cancer therapy with vascular endothelial growth factor inhibitors: understanding and managing a new syndrome. Can J Cardiol 2014;30(5):534-543. 
10. Abernethy DR, Schwartz JB. Calcium-antagonist drugs. N Engl J Med 1999;341(19):1447-1457.

11. Bollée G, Patey N, Cazajous G, et al. Thrombotic microangiopathy secondary to VEGF pathway inhibition by sunitinib. Nephrol Dial Transplant 2009;24(2):682-685.

12. Humphreys BD, Sharman JP, Henderson JM, et al. Gemcitabine-associated thrombotic microangiopathy. Cancer. 2004; 100(12):2664-2670.

13. Izzedine H, Sène D, Hadoux J, et al. Thrombotic microangiopathy related to anti-VEGF agents: intensive versus conservative treatment? Ann Oncol 2011;22(2):487-490.

14. Izzedine H, Brocheriou I, Deray G, et al. Thrombotic microangiopathy and anti-VEGF agents. Nephrol Dial Transplant 2007;22(5):1481-1482.

15. Cavalieri S, Cosmai L, Genderini A, et al. Lenvatinib-induced renal failure: two first-time case reports and review of literature. Expert Opin Drug Metab Toxicol 2018;14(4):379-385.

16. Perico L, Mandalà $M$, Schieppati $A$, et al. BRAF signaling pathway inhibition, podocyte injury, and nephrotic syndrome. Am J Kidney Dis 2017;70(1):145-150.

17. Massey J. Posterior reversible encephalopathy syndrome (PRES) with sub-arachnoid haemorrhage after bevacizumab and 5-FU. J Clin Neurosci 2017;40:57-59.

18. Eryilmaz MK, Mutlu H, Salim DK, et al. Fatal posterior revesible leukoencephalopathy syndrome associated coma induced by bevacizumab in metastatic colorectal cancer and review of literature. J Oncol Pharm Pract 2016;22(6):806-810.

19. Miaris N, Maltezou M, Papaxoinis G, et al. Posterior reversible encephalopathy syndrome with concurrent nephrotic syndrome in a patient treated with pazopanib for metastatic renal cell carcinoma: case report and review of the literature. Clin Genitourin Cancer 2017;15(1):e99-e103.

20. Yılmaz S, Özçakar ZB, Taktak A, et al. Anti-VEGF-related thrombotic microangiopathy in a child presenting with nephrotic syndrome. Pediatr Nephrol 2016;31(6):1029-1032.

21. Wang W, Cheng J, Mallon C, et al. Symptomatic secondary polycythemia induced by anti-vegf therapy for the treatment of metastatic renal cell carcinoma: a case series and review. Clin Genitourin Cancer 2015;13(6):e391-395.

22. Cheungpasitporn W, Chebib FT, Cornell LD, et al. Intravitreal antivascular endothelial growth factor therapy may induce proteinuria and antibody mediated injury in renal allografts. Transplantation 2015;99(11):2382-2386.

23. Haruhara K, Tsuboi N, Nakao M, et al. [A case of glomerulopathy associated with the vascular endothelial growth factor inhibitor bevacizumab]. Nihon Jinzo Gakkai Shi. 2014;56(5):600-605.

24. Usui J, Glezerman IG, Salvatore SP, et al. Clinicopathological spectrum of kidney diseases in cancer patients treated with vascular endothelial growth factor inhibitors: a report of 5 cases and review of literature. Hum Pathol. 2014;45(9): 1918-1927.

25. Georgalas I, Papaconstantinou D, Papadopoulos K, et al. Renal injury following intravitreal anti-VEGF administration in diabetic patients with proliferative diabetic retinopathy and chronic kidney disease--a possible side effect? Curr Drug Saf 2014;9(2):156-158.

26. Pakosch D, Papadimas D, Munding J, et al. Osteonecrosis of the mandible due to anti-angiogenic agent, bevacizumab. Oral Maxillofac Surg 2013;17(4):303-306. 